\title{
Asupan Energi Dan Zat Gizi Makro Terhadap Persen Lemak Tubuh
}

\author{
Farohatus Sholichah $^{1 *}$, Yuli Irnaini Aqnah ${ }^{2}$, Cyntia Ratna Sari ${ }^{3}$ \\ 1,2Program Studi Gizi, Fakultas Psikologi dan Kesehatan, UIN Walisongo Semarang \\ ${ }^{3}$ Program Studi DIV Gizi Klinis, Politeknik Kudus \\ E-mail: *farfar@walisongo.ac.id
}

\begin{abstract}
ABSTRAK
Kebutuhan gizi para santri merupakan salah satu hal yang perlu diperhatikan. Tujuan penelitian ini adalah untuk menganalisis hubungan asupan energi dan zat gizi makro terhadap persen lemak tubuh santriwati. Penelitian dilakukan di Pondok Pesantren Al Asror, Gunungpati, Semarang pada tanggal 21 September 2020-11 Oktober 2020. Penelitian ini menggunakan pendekatan cross sectiona, dengan jumlah sampel sebanyak 38 santriwati, dipilih dengan purposive sampling. Data asupan energi dan zat gizi makro diperoleh dengan food recall 2x24 jam. Data persen lemak tubuh diambil menggunakan Bioelectrical Impedance Analysis (BIA). Data dianalisis univariat dan bivariat (Uji Pearson). Hasil penelitian menunjukkan bahwa rerata asupan energi, karbohidrat, protein, dan lemak responden secara berturut-turut adalah 1009,33 kkal; 137,06 gram; 25,91 gram; dan 40,53 gram. Tidak terdapat hubungan antara asupan energi $(\mathrm{p}=0,467)$, asupan karbohidrat $(\mathrm{p}=0,278)$, asupan protein $(\mathrm{p}=0,643)$, dan asupan lemak $(\mathrm{p}=0,950)$ terhadap persen lemak tubuh.
\end{abstract}

Kata Kunci: asupan energi, asupan zat gizi makro, persen lemak tubuh santri

\begin{abstract}
The nutritional needs of the students is one of the things that needs attention. This study aims to analyze the relationship between energy and macronutrients intake on the body fat percentage of students. The research was conducted at Al Asror Islamic Boarding School, Gunungpati, Semarang on 21 September 2020-11 October 2020. This research is an analytical study with a cross sectional approach. The number of samples in this study were 38 students and were selected by purposive sampling. Energy and macro nutrition intake were obtained with a $2 \times 24$ hour food recall. Body fat percentage was collected using Bioelectrical Impedance Analysis (BIA). Data were analyzed univariate and bivariate (Pearson test). The results showed that the mean intake of energy, carbohydrates, protein, and fat of the respondents were 1009.33 kcal; 137.06 grams; 25.91 grams; and 40.53 grams. There was no relationship between energy intake $(p=0.467)$, carbohydrate intake $(p=0.278)$, protein intake $(p=0.643)$, and fat intake $(p=0.950)$ to the body fat percentage.
\end{abstract}

Keywords: energy intake, macronutrients intake, body fat percentage of students

\section{PENDAHULUAN}

Status gizi merupakan akibat dari asupan makanan dan zat gizi [1]. Berdasarkan Riskesdas (2013), diketahui bahwa status gizi usia 16-18 tahun di Indonesia terdiri atas sangat kurus (1,9\%), kurus $(7,5 \%)$, gemuk $(5,7 \%)$, dan obesitas $(1,6 \%)$. Selanjutnya, pada tahun 2018 prevalensi status gizi usia 16-18 tahun di Indonesia terdiri atas sangat kurus $(1,4 \%)$, kurus $(6,7 \%)$, gemuk $(9,5 \%)$, dan obesitas (4,0\%) [2]. Berdasarkan data tersebut, diketahui bahwa telah terjadi peningkatan Informasi Artikel:

Submitted: bulan Januari 2021, Accepted: bulan Februari 2021, Published: Februari 2021

ISSN: 2716-0084 (media online), Website: http://jurnal.umus.ac.id/index.php/jigk 
prevalensi kegemukan dan obesitas pada remaja usia 16-18 tahun. Di Jawa Tengah, pada tahun 2018 prevalensi status gizi remaja usia 16-18 tahun terdiri atas sangat kurus (1,59\%), kurus $(8,12 \%)$, gemuk $(7,91 \%)$, dan obesitas $(3,66 \%)$. Sementara itu, prevalensi status gizi remaja usia 16-18 tahun di Kota Semarang pada tahun 2018 terdiri atas sangat kurus $(0,43 \%)$, kurus $(11,65 \%)$, gemuk (12,20\%), dan obesitas $(6,92 \%)$ [2]. Hal ini berarti bahwa prevalensi status gizi kurus, gemuk, dan obesitas di Kota Semarang melebihi angka prevalensi di Jawa Tengah.

Kelebihan berat badan erat kaitannya dengan persen lemak tubuh yang tinggi [3]. Tubuh akan mengalami perubahan komposisi ketika memasuki usia remaja, remaja putri menyimpan lebih banyak lemak sehingga persen lemak tubuhnya lebih tinggi disbanding remaja laki-laki, sedangkan remaja laki-laki akan mengalami penambahan massa otot dan jaringan tubuh [4]. Dalam keadaan normal, permulaan usia remaja memiliki persen lemak tubuh sebesar $15-20 \%$ dari berat badan. Rerata persen lemak tubuh akan mengalami peningkatan sesuai dengan pertambahan usia [5]. Persen lemak tubuh yang tinggi dapat mempengaruhi terjadinya berbagai macam penyakit degeneratif [3].

Pondok pesantren merupakan tempat tinggal bagi para santri dalam mempelajari agama Islam [6]. Pemenuhan kebutuhan gizi para santri merupakan salah satu hal yang perlu diperhatikan [7]. Namun, hasil penelitian Rokhmah (2016) menunjukkan bahwa sebagian besar tingkat kecukupan energi dan zat gizi makro pada siswi SMA di pondok pesantren Al Izzah Kota Batu berada dalam kategori inadekuat [8]. Sejalan dengan hasil penelitian tersebut, hasil penelitian Amelia (2013) juga menunjukkan bahwa asupan asupan karbohidrat dan zat gizi lainnya pada santri putri Yayasan Pondok Pesantren Hidayatullah Makassar termasuk dalam kategori kurang [9]. Sementara itu, diketahui bahwa asupan zat gizi merupakan salah satu faktor yang mempengaruhi persen lemak tubuh, selain faktor-faktor seperti pengetahuan gizi, pendidikan, pendapatan keluarga, aktivitas fisik, dan gaya hidup [10]. Pondok Pesantren Al Asror memiliki santri yang mayoritas berusia 16-18 tahun, yaitu sebanyak 275 orang dari 338 santri $(81.36 \%)$. Diantara 338 santri, sebanyak 203 orang diantaranya merupakan santri perempuan atau santriwati (60.06\%). Penelitian ini bertujuan menganalisis hubungan asupan energi dan zat gizi makro terhadap persen lemak tubuh santriwati di Pondok Pesantren Al Asror, Gunungpati, Semarang.

\section{BAHAN DAN METODE}

Penelitian ini dilakukan di Pondok Pesantren Al Asror, Kelurahan Patemon, Kecamatan Gunungpati, Semarang. Penelitian berlangsung pada tanggal 21 September 2020-11 Oktober 2020 menggunakan metode analitik dengan pendekatan cross sectional. Variabel bebas dalam penelitian ini terdiri atas asupan energi dan zat gizi makro (karbohidrat, protein, dan lemak), sedangkan variabel terikatnya adalah persen lemak tubuh. Perhitungan sampel dilakukan menggunakan rumus Slovin, yaitu sebesar 38 santriwati. Penentuan santri sebagai sampel penelitian dilakukan dengan purposive sampling, dengan kriteria inklusi meliputi santriwati berusia 16-18 tahun, tinggal di pondok pesantren, dan bersedia menjadi sampel penelitian. Data asupan energi dan zat gizi makro merupakan jumlah kuantitas makanan santriwati yang diperoleh dengan food) recall 2x24 jam pada weekday (kamis) dan weekend (sabtu). Pengambilan data food recall dilakukan pada hari yang sama untuk meminimalisasi bias yang terjadi terkait kebiasaan makan sampel santriwati. Selain itu, dilakukan juga pengambilan data pola konsumsi santriwati untuk memberikan gambaran data kualitatif terkait kebiasaan makan santriwati yang meliputi jenis makanan pokok, lauk nabati, dan lauk hewani. Data pola konsumsi santriwati digunakan untuk menunjang data kuantitaif asupan energi dan zat gizi makro. Data persen lemak tubuh merupakan data perbandingan antara berat massa lemak dengan total berat badan dalam persen yang diukur dengan menggunakan alat Bioelectrical Impedance Analysis (BIA). Analisis univariat dilakukan untuk mendeskripsikan masing-masing variabel bebas meliputi asupan energi dan asupan zat gizi makro (karbohidrat, protein, serta lemak). Data asupan energi dan zat gizi makro, secara univariat dianalisis dengan membandingkan data terhadap angka kecukupan gizi (AKG) dengan katagori baik ( $\geq 80 \%$ AKG) dan kurang $(<80 \%$ AKG). Data pola konsumsi santri dianalisis secara univariat dengan Informasi Artikel:

Submitted: bulan Januari 2021, Accepted: bulan Februari 2021, Published: Februari 2021

ISSN: 2716-0084 (media online), Website: http://jurnal.umus.ac.id/index.php/jigk 
mengkatagorikan pola konsumsi menjadi tiga katagori yaitu jarang (apabila konsumsi $\leq 1 \mathrm{kali}$ dalam sebulan atau tidak pernah), kadang - kadang (apabila konsumsi 1 - 6 kali dalam seminggu), dan sering (apabila konsumsi $\leq 1$ kali sehari). Analisis univariat juga dilakukan untuk mendeskripsikan variabel terikat yaitu persen lemak tubuh. Data persen lemak tubuh yang diperoleh, dianalisis secara univariat dengan mengkatagorikan persentase lemak tubuh pada perempuan menjadi empat katagori yaitu underfat $(\leq 15 \%)$, healthy/normal $(16-29 \%)$, overfat $(30$ - 34\%), dan obese ( $\geq 35 \%)$. Sementara itu, analisis bivariate untuk menganalisis hubungan antara asupan energi dan zat gizi makro (karbohidrat, protein, serta lemak) dengan persen lemak tubuh dilakukan menggunakan Uji Pearson.

\section{HASIL DAN PEMBAHASAN}

Karakteristik sampel penelitian sejumlah 38 santriwati yang terdiri dari data umur, berat badan, tinggi badan, IMT/U, persen lemak tubuh, rerata sehari asupan energi dan zat gizi makro (karbohidrat, protein, lemak) ditampilkan pada tabel.1. Berdasarkan data karakteristik sampel, diketahui bahwa nilai rerata indeks $Z$ score IMT/U sampel sebesar $0,13 \pm 1,10$, dengan $Z$ score minimal sebesar $-1,85$ dan $Z$ score maksimal 2,29. Temuan data nilai $Z$ score menunjukkan bahwa menurut indikator IMT/U, rata - rata sampel memiliki status gizi baik/normal (-2 SD sd +1 SD), tidak ada sampel yang memiliki status gizi kurang/thinnes (-3 SD sd <-2 SD), tetapi ada sampel yang memiliki status gizi lebih bahkan obesitas (> +2 SD) ditunjukkan dengan ditemukannya nilai maksimal Z score senilai 2,29 SD.

Berdasarkan pengukuran persen lemak tubuh dengan menggunakan Bioelectrical Impedance Analysis (BIA) pada 38 sampel santriwati, menunjukkan bahwa data persen lemak tubuh santriwati berditribusi normal dengan rentang data antara $12,40 \%-38,60 \%$, dengan nilai rerata sebesar $26,99 \%$. Temuan data persen lemak tubuh pada penelitian ini menunjukkan bahwa rata - rata santriwati memiliki persen lemak tubuh yang normal antara $25-30 \%$ ditunjukkan dengan rerata data persen lemak tubuh sebesar 26,99\%. (26,99 $\pm 5,19)$. Dalam penelitian ini rerata persen lemak tubuh lebih tinggi dibandingkan dengan penelitian sebelumnya pada remaja putri SMA/MA/SMK di Kecamatan Kedungbanteng, Kabupaten Banyumas yang memiliki rerata sebesar 23,61\% [11].

Persen lemak tubuh merupakan persentase perbandingan massa jaringan lemak dan non lemak (fat free mass) pada tubuh seseorang. Persen lemak tubuh yang tinggi juga dapat menyebabkan obesitas. Pada penelitian di Kecamatan Losari, Kabupaten Brebes menunjukkan terdapat hubungan yang signifikan antara asupan makan dengan kejadian obesitas pada buruh perempuan di pabrik rajungan [12]. Selain mempengaruhi bentuk tubuh dan berat badan, persen lemak tubuh juga mempengaruhi kesegaran jasmani seseorang, semakin meningkat persen lemak tubuh akan semakin turun pula jasmaninya [13]. Hal tersebut berdampak terhadap kesehatan seseorang. Bahkan, persen lemak tubuh lebih akurat dalam mengetahui penyakit yang berkaitan dengan berat badan, daripada menggunakan pengukuran Indeks Massa Tubuh (IMT). Dalam keadaan normal, permulaan usia remaja memiliki persen lemak tubuh sebesar 15-20\% dari berat badan. Persen lemak tubuh dipengaruhi oleh faktor genetik, usia jenis kelamin, kondisi psikologis, pola makan, dan aktivitas fisik. Rata-rata persen lemak tubuh akan mengalami peningkatan sesuai dengan pertambahan usia dan seseorang dengan jenis kelamin perempuan cenderung memiliki persen lemak tubuh yang lebih tinggi dibanding seseorang yang berjenis kelamin laki - laki [5]. Pada penelitian ini, rerata persen lemak tubuh santriwati sebesar 26,99\%. Hal ini menunjukkan bahwa rerata persen lemak tubuh santriwati berada pada katagori normal fat (>16 s.d <31) apabila dibandingkan dengan klasifikasi persen lemak tubuh menurut Jebb S McCarhy dan D, Fry T.

Rerata asupan energi, karbohidrat, protein, dan lemak responden dalam penelitian ini secara berturut-turut adalah 1009,33 kkal; 137,06 gram; 25,91 gram; dan 40,53 gram. Terkait asupan energi dan zat gizi, diketahui bahwa Berdasarkan Permenkes No. 28 Tahun 2019, Angka kecukupan Gizi (AKG) energi, karbohidrat, protein, dan lemak masing-masing pada perempuan usia 16-18 tahun adalah sehesar $2100 \mathrm{kkal} ; 300 \mathrm{gram} ; 65 \mathrm{gram} ;$ dan 70 gram Dengan demikian, 
rerata asupan energi, karbohidrat, protein, dan lemak responden masih di bawah AKG yang dianjurkan per hari.

Tabel 1. Karakteristik Responden

\begin{tabular}{lcccc}
\hline Karakteristik (n = 38) & Minimal & Maksimal & \multicolumn{2}{c}{ Rerata \pm SD } \\
\hline Umur (tahun) & 16 & 18 & 16,61 & $\pm 0,71$ \\
Berat Badan (kg) & 37 & 74 & 50,51 & $\pm 8,98$ \\
Tinggi Badan (cm) & 143 & 163 & 152,47 & $\pm 5,15$ \\
IMT/U (Z score) & $-1,85$ & 2,29 & 0,13 & $\pm 1,10$ \\
Persen Lemak Tubuh (\%) & 12,40 & 38,60 & 26,99 & $\pm 5,19$ \\
Asupan Energi (kkal) & 522,50 & $1.592,50$ & $1.015,56 \pm 271,17$ \\
Asupan Karbohidrat (gram) & 130 & 85 & 137,15 & $\pm 30,63$ \\
Asupan Protein (gram) & 10,35 & 55,10 & 25,97 & $\pm 8,16$ \\
Asupan Lemak (gram) & 14,90 & 80 & 40,92 & $\pm 18,03$ \\
\hline
\end{tabular}

Gambaran profil status gizi, asupan zat gizi, persen lemak tubuh, dan frekuensi pola konsumsi pangan ditampilkan pada tabel 2. Berdasarkan data hasil penelitian mengenai status gizi menurut IMT/U, diketahui bahwa sebagian besar sampel memiliki status gizi baik yaitu sejumlah 26 santriwati $(71,3 \%)$. Terdapat 1 santriwati $(2,6 \%)$ yang memiliki gizi kurang dan terdapat 10 santriwati yang memiliki status gizi yang memiliki status gizi lebih dan obes $(26,1 \%)$.

Data persen lemak tubuh dikatagorikan menjadi empat katagori menurut Jebb S McCarhy dan D, Fry T yaitu underfat, healthy/normal, overfat, dan obese. Didapatkan hasil bahwa sebagian besar sampel memilki persen lemak tubuh healthy/normal yaitu sebanyak 31 santriwati $(82,1 \%)$, dan sisanya sebanyak 7 santriwati $(17,9 \%)$ memiliki persen lemak tubuh katagori overfat dan obesse.

Data asupan energi dan zat gizi makro sampel menunjukkan hasil yang hampir sama bahwa sebagian besar santriwati memiliki asupan energi, karbohidrat, protein, dan lemak yang cenderung kurang dari kebutuhan sehari menurut angka kecukupan gizi (AKG) yang dianjurkan. Bahkan seluruh sampel memiliki asupanan energi dan karbohidrat dibawah $80 \%$ dari kebutuhan sehari yang dianjurkan.

Tabel 2. Gambaran Sampel Santriwati Berdasarkan Profil Status Gizi, Asupan Zat Gizi, Persen Lemak Tubuh, dan Frekuensi Pola Konsumsi Pangan

\begin{tabular}{lccc}
\hline Variabel $(\mathbf{n}=\mathbf{3 8})$ & Indikator & $\mathbf{n = 3 8}$ & $\mathbf{\%}$ \\
\hline Status gizi (IMT/U) & & & \\
Kurang & -3 SD sd <-2 SD & 1 & 2,6 \\
Baik & -2 SD sd +1 SD & 26 & 71,3 \\
Overweight & $>+1$ SD sd +2 SD & 8 & 20,8 \\
Obesitas & $>+2$ SD & 2 & 5,3 \\
& & & \\
Persen lemak tubuh & $\leq 15$ & - & - \\
Underfat & $16-29$ & 31 & 82,1 \\
Healthy/normal & $30-34$ & 6 & 15,3 \\
Overfat & &
\end{tabular}

Informasi Artikel:

Submitted: bulan Januari 2021, Accepted: bulan Februari 2021, Published: Februari 2021

ISSN: 2716-0084 (media online), Website: http://jurnal.umus.ac.id/index.php/jigk 


\begin{tabular}{|c|c|c|c|}
\hline Obese & $\geq 35$ & 1 & 2,6 \\
\hline \multicolumn{4}{|c|}{ Kecukupan asupan energi } \\
\hline Kurang & $<80 \% \mathrm{AKG})$ & 38 & 100 \\
\hline Baik & $\geq 80 \% \mathrm{AKG}$ & - & - \\
\hline \multicolumn{4}{|l|}{ Kecukupan asupan } \\
\hline \multicolumn{4}{|l|}{ karbohidrat } \\
\hline Kurang & $<80 \% \mathrm{AKG})$ & 38 & 100 \\
\hline Baik & $\geq 80 \% \mathrm{AKG}$ & - & - \\
\hline \multicolumn{4}{|c|}{ Kecukupan asupan protein } \\
\hline Kurang & $<80 \%$ AKG) & 37 & 97,4 \\
\hline Baik & $\geq 80 \% \mathrm{AKG}$ & 1 & 2,6 \\
\hline \multicolumn{4}{|c|}{ Kecukupan asupan lemak } \\
\hline Kurang & $<80 \% \mathrm{AKG})$ & 27 & 71,8 \\
\hline Baik & $\geq 80 \% \mathrm{AKG}$ & 11 & 28,2 \\
\hline \multicolumn{4}{|c|}{ Frekuensi makanan pokok } \\
\hline Jarang & $\leq 1$ kali sebulan & - & - \\
\hline Kadang - kadang & $1-6$ kali seminggu & - & - \\
\hline Sering & $\geq 1$ kali sehari & 38 & 100 \\
\hline \multicolumn{4}{|c|}{ Frekuensi lauk hewani } \\
\hline Jarang & $\leq 1$ kali sebulan & 2 & 5,2 \\
\hline Kadang - kadang & $1-6$ kali seminggu & 28 & 74,0 \\
\hline Sering & $\geq 1$ kali sehari & 8 & 20,8 \\
\hline \multicolumn{4}{|c|}{ Frekuensi lauk nabati } \\
\hline Jarang & $\leq 1$ kali sebulan & - & - \\
\hline Kadang - kadang & $1-6$ kali seminggu & 6 & 15,3 \\
\hline Sering & $\geq 1$ kali sehari & 32 & 84,7 \\
\hline
\end{tabular}

Data pola konsumsi asupan energi dan zat gizi makro yang ditunjukkan dengan frekuensi makanan pokok, lauk hewani, dan nabati juga menggambarkan bahwa ragam asupan dan jenis makanan santriwati masih belum seimbang dan beragam. Terdapat kecenderungan bahwa proporsi asupan makan sehari terutama didominasi oleh jenis bahan makanan pokok dan lauk nabati, sedangkan sebagian besar sampel yaitu 28 santriwati (74\%) tidak selalu mengonsumsi lauk hewani setiap hari.

Pada usia remaja terjadi peningkatan pertumbuhan yang berlangsung secara cepat kemudian menurun pada usia 17-18 tahun [14]. Pola makan pada remaja seringkali kurang baik yang berdampak pada terjadinya malnutrisi. Remaja kerap melewatkan sarapan, jarang mengonsumsi sayur dan buah serta melakukan diet yang salah terutama pada remaja putri sehingga menyebabkan asupan makanan tidak sesuai dengan kebutuhan [15].

Asupan makanan yang tidak sesuai dapat menyebabkan perubahan komposisi tubuh [16]. Jumlah asupan makanan bukan merupakan faktor satu-satunya yang perlu diperhatikan. Kepadatan energi dari makanan juga penting untuk diperhatikan. Zat gizi makro seperti karbohidrat, protein, dan lemak masing-masing memiliki kontribusi jumlah kalori yang tidak sama. Kalori yang dihasilkan dari 1 gram protein dan karbohidrat adalah 4 kalori sedangkan 1 gram lemak menghasilkan 9 kalori. Massa tubuh tanpa lemak atau lean body mass pada remaja harus dipertahankan dengan mengatur asupan protein. Selain mempertahankan, jumlah kebutuhan protein remaja juga diperlukan dalam rangka peningkatan massa tubuh tanpa lemak selama masa pertumbuhan (growth spurt). Masa growth spurt berlangsung pada usia 11-14 tahun pada perempuan dan usia 15-18 tahun pada laki-laki. Pada masa growth spurt, kebutuhan protein berada pada angka tertinggi. Asupan protein diperlukan bagi tumbuh kembang remaja, selain asupan energi. Apabila terjadi kekurangan asupan protein pada masa tersebut, maka dapat mengakibatkan terjadinya pertumbuhan linear yang kurang optimal dan keterlambatan maturasi (kematangan) seksual. Selain itu, kekurangan asupan protein pada masa remaja dapat mengakibatkan pengurangan akumulasi lean body mass. Tidak hanya kekurangan, kelebihan asupan protein juga dapat berefek pada berat badan seseorang.

Informasi Artikel:

Submitted: bulan Januari 2021, Accepted: bulan Februari 2021, Published: Februari 2021

ISSN: 2716-0084 (media online), Website: http://jurnal.umus.ac.id/index.php/jigk 
Terkait analisis bivariat, hasil Uji Pearson menunjukkan bahwa tidak terdapat hubungan antara asupan energi dengan persen lemak tubuh $(\mathrm{p}=0,467)$. Asupan karbohidrat juga tidak berhubungan dengan persen lemak tubuh $(\mathrm{p}=0,278)$. Hasil uji korelasi Pearson juga menunjukkan tidak terdapat hubungan antara asupan protein dan asupan lemak terhadap persen lemak tubuh, dengan masing-masing nilai $\mathrm{p}=0,643$ dan $\mathrm{p}=0,950$. Hasil Uji Korelasi Pearson dapat dilihat pada Tabel 3 berikut ini:

Tabel 3. Hubungan Asupan Energi dan Zat Gizi Makro terhadap Persen Lemak Tubuh

\begin{tabular}{lcc}
\hline \multirow{2}{*}{ Variabel } & \multicolumn{2}{c}{ Persen Lemak Tubuh } \\
\cline { 2 - 3 } & P & R \\
\hline Asupan Energi & 0,467 & 0,122 \\
Asupan Karbohidrat & 0,278 & 0,181 \\
Asupan Protein & 0,643 & 0,078 \\
Asupan Lemak & 0,950 & $-0,011$ \\
\hline
\end{tabular}

Hasil penelitian ini sejalan dengan hasil penelitian Habibaturochmah (2014) yang menunjukan bahwa tidak terdapat hubungan antara asupan energi dan protein terhadap persen lemak tubuh pada remaja putri di SMP Pangudi Luhur Semarang. Pada penelitian ini menyebutkan asupan energi yang tidak berhubungan dengan persen lemak tubuh kemungkinan terjadi karena responden dalam penelitian yang memiliki tubuh kurus cenderung melaporkan konsumsi yang lebih banyak [17]. Sebaliknya responden yang bertubuh gemuk cenderung melaporkan konsumsi yang lebih sedikit (the flat slope syndrome) saat wawancara berlangsung. Sementara asupan protein yang tidak berhubungan terjadi karena biasanya protein digunakan untuk membentuk atau mengganti jaringan baru, sehingga proses dirubahnya protein menjadi energi tidak langsung terjadi. Salah satu studi yang membahas mengenai pengaruh diet tinggi protein terhadap persen lemak tubuh menjelaskan bahwa diet tinggi protein cenderung menurunkan persen lemak tubuh [18]. Hasil penelitian Heriyanto (2012) juga menyatakan bahwa tidak terdapat hubungan antara asupan energi, protein, dan karbohidrat terhadap persen lemak tubuh [19].

Asupan karbohidrat yang tidak berhubungan dengan persen lemak tubuh kemungkinan karena energi yang dihasilkan dari karbohidrat biasanya digunakan terlebih dahulu sehingga memungkinkan energi dari asupan karbohidrat tidak disimpan kembali dalam bentuk lemak. Pengubahan karbohidrat menjadi lemak kurang efisien, karena membutuhkan 23\% dari kalori yang dicerna. Pada penelitian ini tidak terdapatnya hubungan antara asupan energi dan zat gizi terhadap persen lemak tubuh dapat disebabkan karena nilai rerata asupan energi dan zat gizi santriwati yang masih belum memenuhi AKG yang dianjurkan per hari. Selain itu, terdapat faktor lain yang dapat mempengaruhi persen lemak tubuh, seperti kebiasaan sarapan [20]. Frekuensi mengonsumsi fast food juga berpengaruh terhadap persen lemak tubuh [21].Tidak hanya itu, aktivitas fisik juga berpengaruh terhadap status gizi remaja [22].

Nutrisi makro tertentu memiliki pengaruh kenyang dan termal yang tidak sama serta dapat mempengaruhi pengeluaran energi. Komposisi makanan serta efisiensi metabolisme lemak dapat berpengaruh terhadap penyimpanan energi.

\section{KESIMPULAN}

Kesimpulan yang dapat diambil dari hasil penelitian ini yaitu asupan energi dan zat gizi makro responden masih di bawah AKG yang dianjurkan per hari. Hasil penelitian juga menunjukkan bahwa tidak terdapat hubungan antara asupan energi dan zat gizi makro terhadap persen lemak tubuh santriwati Pondok Pesantren Al Asror ( $p>0,05)$.

\section{SARAN}

Informasi Artikel:

Submitted: bulan Januari 2021, Accepted: bulan Februari 2021, Published: Februari 2021

ISSN: 2716-0084 (media online), Website: http://jurnal.umus.ac.id/index.php/jigk 
Bagi penelitian selanjutnya, disarankan untuk menganalisis variabel-variabel lainnya yang dapat berpengaruh terhadap persen lemak tubuh santriwati. Selain itu, penelitian selanjutnya juga dapat menggunakan jenis metode penelitian yang berbeda.

\section{DAFTAR PUSTAKA}

[1] Almatsier S. Prinsip Dasar Ilmu Gizi. Jakarta: Gramedia Pustaka Utama.2010.

[2] Riskesdas. Hasil Utama Riskesdas 2018. Jakarta: Kemenkes RI. 2018.

[3] Adityawarman. Hubungan Aktivitas Fisik dengan Komposisi Tubuh pada Remaja. Skripsi. Semarang: Universitas Diponegoro. 2007.

[4] Putri, Riana, Auza. Faktor-Faktor yang Berhubungan dengan Persen Lemak Tubuh pada Siswi SMA Al Azhar I dan SMK Negeri 8 Jakarta Selatan Tahun 2004. Skripsi. Jakarta: Universitas Indonesia. 2004.

[5] Adiningsih S. Ukuran Pertumbuhan dan Status Gizi Remaja Awal. Makalah disajikan dalam KONAS XII PERSAGI. 2002.

[6] Ghozali. Pesantren Berwawasan Lingkungan. Jakarta: CV Prasasti. 2003.

[7] Khazanah N. Sistem Penyelenggaraan Makanan di Pondok Pesantren Darul Muttaqien (Santri Putri) Parung Bogor Tahun 2010. Jakarta: UIN Syarif Hidayatullah. 2010.

[8] Rokhmah F, Muniroh L, Nindya T. Hubungan Tingkat Kecukupan Energi dan Zat Gizi Makro dengan Status Gizi Siswi SMA di Pondok Pesantren Al-Izzah Kota Batu. Media Gizi Indonesia. 2016; 11 (1): 94-100.

[9] Amelia A, Syam, A, St Fatimah. Hubungan Asupan Energi dan Zat Gizi dengan Status Gizi Santri Putri Yayasan Pondok Pesantren Hidayatullah Makassar Sulawesi Selatan Tahun 2013. Jurnal Universitas Hasanuddin Makassar. 2013.

[10] Bowman S.A \& Vinyard B.T. Fast Food Consumption of Us Adults: Impact on Energy and Nutrient Intakes and Overweight Status. Jurnal of The American College of Nutrition. 2004; 23 (2): 163-168.

[11] Zaki I, Sari, HP, Farida. Konsumsi Air Berkolerasi dengan Persen Lemak Tubuh Remaja Putri di Kawasan Perdesaan Kabupaten Banyumas. J.Gipas. 2018; 2(1): 2599-0152.

[12] Koryaningsih A \& Wahyani AD. Hubungan antara Asupan Energi dan Aktivitas Fisik dengan Obesitas pada Buruh Perempuan. Jurnal Ilmiah dan Gizi Kesehatan. 2019; 1(1): 1118.

[13] Murbawani EA. Hubungan Persen Lemak Tubuh dan Aktifitas Fisik dengan Tingkat Kesegaran Jasmani Remaja Putri. Journal of Nutrition and Health. 2017; 5(2): 69-84.

[14] Pieter HZ, \& Lubis NL. Pengantar Psikologi untuk Kebidanan. Jakarta: Prenadamedia. 2013.

[15] Pane, Herviza W, Tasnim, Sulfianti, Hasnidar, Puspita R. Gizi dan Kesehatan. 2020.ISBN: 978-623-94636-3-2.

[16] Setiowati A. Hubungan Indeks Masa Tubuh, Persen Lemak Tubuh, Asupan Zat Gizi dengan Kekuatan Otot. Jurnal Media Ilmu Keolahragaan Indonesia. 2014; 4(1): 2088-6802.

[17] Habibaturochmah \& Fitranti DY. Hubungan Konsumsi Air, Asupan Zat Gizi, dan Aktifitas Fisik dengan Persen Lemak Tubuh Pada Remaja Putri. Journal of Nutrition College. 2014; 3(4): 595-603.

[18] Setiowati A. Pengaruh Diet Tinggi Protein terhadap Indeks Massa Tubuh, Persen Lemak Tubuh, Kekuatan Otot dan Kecepatan pada Atlet. Skripsi. Semarang:Universitas Diponegoro. 2013.

[19] Heriyanto, Mira H. Hubungan Asupan Gizi dan Faktor Lain dengan Persen Lemak Tubuh pada Mahasiswi Prodi Gizi dan Ilmu Komunikasi UI Angkatan 2009 Tahun 2012. Skripsi: Fakultas Kesehatan Masyarakat, Universitas Indonesia. 2012. 
[20] Smith KJ, Gall SL, McNaughton SA, Blizzard, Leigh, Dwyer, Terence, Venn AlJ. Skipping Breakfast: Longitudinal Associations with Cardiometabolic Risk Factors in The Childhood Determinants of Adult Health Study. Am J Clin Nutr. 2010; 92(6):1316-25.

[21] French SA, Harnack L, Jeffery RW. Fast Food Restaurant Use Among Women in the Pound of Prevention Study: Dietary, Behavioral, and Demographic Correlates. In J Obes Relat Metab Disord. 2000; 24(10): 1353-9.

[22] Troiano RP, Briefel RR, Carroll MD, Bialostosky K. Energy and Fat Intakes of Children and Adolescents in The United States: Data from The National Health and NutritionExamination Surveys. Am J Clin Nutr. 2000; 72(5 Suppl): 1343S-1353S. 